\title{
シンポジウム $1-5$
}

\section{痛風・高尿酸血症治療薬フェブリク ${ }^{\circledR} の$ 前臨床開発}

新しい痛風・高尿酸血症治療薬創製のため，尿 酸生成に関わるキサンチン酸化還元酵素（XO） に着目し，既存薬に対してより強力で，使いやす い薬剤を目指して探索研究を行った. 本領域では, 1960年代にアロプリノールが登場して以来，尿 酸産生阻害剂の研究が世界中で活発に行われた が，いずれの候補化合物も開発に至らなかった。 その要因として，XOに対する基本的な阻害作用 が不十分であったこと，及び核酸塩基構造（プリ ン骨格）に由来する副作用のためと考え，阻害作 用の高活性化とともに，核酸代謝酵素への影響を 排除し，腎機能低下患者でも安全に使えるよう， 腎排泄性を軽減した薬剤の開発を目指した。

過去の開発候補品の解析から, 非プリン骨格で も XO 阻害活性を発揮しうることを突きとめ， 5 員環 -6 員環を基本テンプレートとして種々の母 核を検証した。その結果, 2-アリールチアゾール 誘導体が弱いながらも XO 阻害活性を持つことを 発見した。これをリード化合物として，効率的な 構造展開と薬物動態的な評価手法により, $\mathrm{Ki}$ 值 が0.1nM という極めて強いXO 阻害活性を持ち, かつ，優れた薬物動態特性を有するフェブキソス タット（フェブリク®）の合成に成功した，X線 によるXO との共結晶解析から, 本化合物が酵素 の活性中心の近辺で空間によくはまり，周囲のア ミノ酸と強く相互作用していることが明らかとな
近藤 史郎

り, 本化合物の阻害活性の強さがタンパク構造学 的にも裏付けられた。

次いで，チンパンジーを含めた種々の動物モデ ルで血中尿酸低下作用を検討し，いずれの動物モ デルでもアロプリノールより 3 倍から 10 倍程度強 い効力を持つことを確認した。またプリン骨格を 排除することで，PNP， HGPRT や OPRT など, 重要なプリン・ピリミジン代謝酵素に対し, $100 \mu \mathrm{M}$ の高濃度まで影響がないことを明らかに した。さらに長期かつ詳細な安全性試験，品質試 験等を実施して，臨床研究段階に進めた。種々の 臨床試験の結果, 本剤は1日1回, かつ $20 \mathrm{mg}$ か ら 40mg の低用量で高い有効性を持つことが示さ れた。さらに本剤は尿中排泄性が約 $50 \%$ と低い ため，軽度から中等度の腎機能低下患者において も，用量の調節をすることなく同等の有効性と忍 容性が示された。

すでに欧米を中心に海外10ケ国以上で承認さ れ，日本国内でも2011年から販売が開始された。 本領域で 40 年ぶりとなる日本発の新薬として, 患者さんに新しい治療手段を提供することが可能 になった。さらに活性酸素の発生源としてのXO の役割, 及び, 尿酸代謝と腎機能障害やメタボリッ クシンドロームなどとの関連性に関する新しい研 究の端緒となることを期待している. 